\title{
KNOWLEDGE TRANSFER THROUGH INTERNATIONAL ASSIGNMENTS IN THE ORGANIZATIONAL CONTEXT
}

The main goal of this paper is to contribute to a better understanding of knowledge transfer within international assignments (IAs). The author's intention was to develop a theoretical model which illustrates the complexities of this process, and emphasizes the role of support provided by a company. As the latter is not only an interesting field for theoretical exploration, but also represents an important challenge for managers and assignees in multinational companies, the study provides the conceptual framework, and an exemplification of the above issue based on three Polish MNCs' experiences.

Keywords: international assignments, knowledge transfer, conceptualization, organizational context

DOI: $10.15611 /$ aoe.2015.2.08

\section{INTRODUCTION}

Every company is a social community "that specializes in the creation and internal transfer of knowledge" (Kogut, Zander 1993). However, cross-border transfers are recognized as critical issues for multinational corporations (MNCs). In light of the evolutional theory by Kogut and Zander (1993), the ability to transfer and recombine knowledge in units operating in different parts of the world enables a company to expand internationally. Among numerous tools facilitating such transfers, international assignments (IAs) seem to be a useful and popular solution (Dickmann, Müller-Camen 2006). Knowledge transferred by assignees is diverse in terms of complexity as well as formalization and intangibility, it includes a collective and individual experience. Its properties (i.e. ambiguity and 'unprovenness') and forms (more or less structured and codified) can strongly affect the cost, ease, or even feasibility of the transfer (Polanyi 1962; Szulanski 2003). Additionally, empirical findings suggest that certain qualities of the actors participating in such a transfer, and the relationship between them, may create relevant obstacles (Szulanski 2003). Moreover, the impact of other context factors representing the organizational and national level cannot be underestimated

\footnotetext{
* Cracow University of Economics
} 
(Kostova 1999). Summing up, the choice of an appropriate mode of international assignment requires a thorough analysis of the knowledge to be transferred and the circumstances of the interaction between the donor and recipient, which means relationships between individuals from different locations and between units (i.e. headquarters/subsidiaries/branches/affiliates). This choice, undoubtedly, does not guarantee that an assignee will succeed as a transferor, moreover, it rather evokes many questions, inter alia: How can the company support knowledge flow through cross-border personal interactions? To what extent such support requires adjustment to individuals' characteristics and specificity of the knowledge transfer? What are the major challenges for organizations using IAs as a means of knowledge transfer?

Accordingly, the aim of this paper is to contribute to a better understanding of knowledge transfer through international assignments by providing a theoretical framework comprising its interpersonal and organizational aspects. Furthermore, it is particularly focused on the role of a company in this process - as a source of support, and the context within which such transfers take place. This issue represents not only an interesting field for theoretical exploration, but also as a practical problem of growing importance for companies undertaking or pursuing international expansion, including Polish-based enterprises. Therefore the study encompasses two interrelated parts, the first discusses the theoretical background and provides a conceptual framework of knowledge transfer via IAs, while the second serves as an exemplification of the above issue. The latter is aimed to (1) illustrate the organizational approaches and practices used by three Polishbased MNCs in the process of delegating employees abroad, (2) determine the importance of knowledge transfer as a task of assignees, (3) find out organizational solutions supporting/facilitating knowledge transfers through IAs, and (4) identify key problems and the challenges accompanying them. The following sections contain a discussion of cross-border knowledge transfers and international assignments, a presentation of the aforementioned framework, and an example of its application. Finally, conclusions to future research and practice are drawn.

\section{CROSS-BORDER KNOWLEDGE TRANSFER AND ITS MECHANISMS}

Since knowledge is an ambiguous and sometimes overused notion, the author has adapted a definition based on Kogut and Zander's (1993) seminal work on the evolutional theory of a multinational company. As a 
consequence, this term is used to describe a recipe that specifies how to carry out the activities and competences (i.e. skills) necessary to do it $^{1}$. It includes, therefore, diverse forms, individual and collective (embedded in personal or group experience), which can be characterized in terms of tacitness (or explicitness), and being firm specific (or generic) (Bonache, Zárraga-Oberty 2008). According to a resource-based view, knowledge performs the main role in achieving and sustaining a competitive advantage by a company, particularly if its attributes are rareness, high value, being difficult to imitate or substitute (Wernerfelt 1984). An important implication of such a perspective is that this kind of resource offers an opportunity to expand not only in domestic but also overseas markets. However, in light of the evolutionary theory, the crucial condition of company international expansion is developing efficient mechanisms of cross-unit transfer that allow to benefit from existing resources and access to new (local) knowledge on a worldwide scale (Kogut, Zander 1993; Teece et al. 1997). They are supposed to enable or facilitate the dissemination of valuable know-how, and the practices and skills that were created or developed in any part of the organization. Therefore, diverse directions of knowledge flows can be distinguished from headquarters to subsidiaries, from subsidiaries to headquarters, or between subsidiaries (see: Gupta, Govindarajan 2000; Harzing, Noorderhaven 2006).

Due to dynamic changes in communication technology, the range of available modes of intra-organizational transfer has widened substantially over the last few decades. Consequently, MNEs tend to use a variety of mechanisms, sometimes simultaneously, including: centres of excellence, global systems of knowledge management based on technology, international management teams, communities of practice/global expertise networks, and international assignees (Sparrow 2006). Some of them are based on formal roles and procedures (e.g. reporting, databases, repositories, and Intranet-based tools for knowledge sharing), while others rely on social interactions (e.g. multinational teams, communities of practice) and/or involve establishing direct, personal contacts (IAs) (Dickmann, MüllerCarmen 2006). However it can be expected that the occurrence and use of these instruments in the MNE is diverse, among other reasons, due to the specific features of the company, the nature of the knowledge transferred, and many other contingency factors. At the same time, the selection of

\footnotetext{
${ }^{1}$ Inclusion of individual knowledge, experience and skills in this modification of the original definition is based on the assumption that, in the case of cross-border transfers by means of IAs, separating less codified organizational know-how from subjective interpretations based on personal knowledge of an individual is impossible and artificial.
} 
adequate mechanisms is an essential success factor of the cross-border transfer. The more intangible the knowledge to be transnationally transferred, the higher the need to use interactive solutions facilitating the dialogue among its participants. In MNEs, the basic element to meet the above requirement is an international assignment (IA).

\section{IAS AS A TOOL OF CROSS-BORDER KNOWLEDGE TRANSFER}

In the literature, the use of IAs for knowledge transfer within the MNE has been the focus of researchers' interest for decades, as one of the problems of strategic importance for the development of a company's activities beyond its home country's borders. As early as the 1970s, Edstörm and Galbraith (1977) emphasized the presence of the motive of knowledge export from the company head office to its foreign subsidiaries through its representatives under conditions of the unavailability of local employees endowed with the appropriate skills/expertise. Recent research suggests that the importance of the aforementioned motive has been increasing gradually, and nowadays knowledge transfer has become the most typical reason for sending employees to foreign subsidiaries (Executive Report 2000). However, until recently, the majority of studies and publications have been devoted only to long-term international assignments, whereas alternative forms and directions of expatriation ${ }^{2}$, as well as conditions of knowledge transfer through assignments, represent less recognized issues ${ }^{3}$.

The knowledge transferred by means of IAs is diverse from the point of view of its level of formalizing, intangibility, and the scope of its sharing by others (it may be collective - embedded in organizational practices, or rather personal, as a unique result of individual experience, observations and reflections). Thus, assignees transmit the organizational know-how (including techniques, standards and procedures), disseminate corporate behavioural patterns and develop the competence of employees in the host

\footnotetext{
${ }^{2}$ The term 'expatriation' is used as a synonym to international assignments, except when it is preceded by adjectives indicating particular type(s) of assignments (e.g. long-term = traditional, or short-term).

${ }^{3}$ Examples of publications referring to non-standard assignments are (Mayerhofer et al. 2004; Reiche 2006; Starr, Currie 2009; Starr 2009) whereas the problem of conditions and barriers of knowledge transfers in the multinational organization was undertaken by Kostova (1999) and Szulanski (2003). The IAs as one of the mechanisms of know-how transfer in the scope of human resources management was recognised by Bonache and Brewster (2001), Bonache and Dickmann(2008), Dickmann and Müller-Carmen (2006), and Bonache and ZárragaOberty(2008).
} 
business unit through common work, teaching and experience sharing, inspiring, and motivating (see: Dowling et al. 2008: pp. 92-95).

In general, the more tacit its nature, the more personal mechanisms of transfer are desired (in comparison to other mechanisms). However, the type of knowledge can be regarded as a factor determining both the action to be taken by an assignee, and the specific requirements concerning the duration and form of assignment. For instance, Bonache and Zárraga-Oberty (2008) hypothesized that the transfer of tacit and individual knowledge involved individual assignment, while collective forms required team assignments. Moreover, they suggested that more specific, narrow knowledge requires relatively short-time IAs, while generic knowledge is more likely to be transferred through long-time expatriation. Since all assignees, to some extent, are involved in social interactions which enable the flow of nonexplicit knowledge (between assignees and host co-workers), the characteristics of all transfer participants, and the relationship between them, might be at least as important success factors as the quality and adequacy of transfer mechanisms (Nahapiet, Goshal 1998; Szulanski2003; Bonache, Zárraga-Oberty 2008; Bonache, Dickmann 2008). Nevertheless, this direct interaction between assignee and local employee cannot be considered in separation from its complex, international context. The country-related aspects of this process have already been appreciated in literature, as some authors have pointed to cultural ${ }^{4}$ and institutional ${ }^{5}$ environments (in both home and host countries) as factors affecting organizational practices, individual attitudes, and behaviour (Kostova 1999; Zhu 2002). An important, yet less explored issue, is the internal ( within an MNC) context of knowledge transfer in MNEs, which is assumed to affect its success by exerting an influence on participants and the relationship between them (Kostova 1999; Bonache, Dickmann 2008).

Therefore the framework of knowledge transfer through IAs as discussed further (see: Figure 1), conceptualizes the context of this process by developing an organization background.

\footnotetext{
${ }^{4}$ Two cultural dimensions are supposed to play an important role in determining preferences of management and employees in MNEs concerning its international activities: power distance and uncertainty avoidance (Hofstede, Hofstede 2007, pp. 70, 206, 356). They both can substantially affect managing expatriation, developing relationships and trust, knowledge sharing (Harzing, Sorge 2003; Zarzadzanie kadra ... 2008; Zarzązanie misjami ... 2011).

${ }^{5}$ Institutional environment, regarded as a component strictly related to culture, exerts influence in the three following ways: through establishing and maintaining a regulatory framework, through defining desired goals and the means appropriate to achieve them, and through affecting individual beliefs and opinions by institutions (Noorderhaven, Harzing 2003, p. 57).
} 


\section{ORGANIZATIONAL CONTEXT OF KNOWLEDGE TRANSFER BY INTERNATIONAL ASSIGNMENTS}

With regard to the organizational context of knowledge transfer via IAs, the following interrelated facets emerge from literature studies:

a) Strategic, by which the strategic orientation of an $\mathrm{MNC}^{6}$ corporate and/or functional strategies concerning knowledge management (Hansen et al 1999), and human resource management (Międzynarodowe zarządzanie ... 2002; Dowling et al. 2008; Evans et al. 2011) can be considered as a framework or guidelines for establishing the transfer-related goals of IAs, or determining the roles of the assignees (as knowledge transferors). Accordingly, the analysis of strategic context, in terms of its supportive/discouraging role, should determine whether these 'strategic guidelines':

- emphasize the need/importance of knowledge transfer between the dispersed units of an $\mathrm{MNC}$ at corporate and unit (i.e. subsidiary/affiliate) levels;

- appreciate the need/importance of interpersonal relationships as a mechanism of transnational knowledge flow;

- are fully understood and accepted by managers involved in developing, implementing and supervising these strategies at corporate and subsidiary level;

- are clearly communicated to assignees (as goals/tasks), agreed (by all parties involved in knowledge transfer) and evaluated (measured/monitored) throughout the whole sojourn in the host unit, and after completing the assignment.

b) Cultural, as far as the organizational culture is regarded as the source of common values, shared understanding, sense of integrity and identity, and patterns of behaviour, which in turn may affect:

\footnotetext{
${ }^{6}$ With regard to knowledge transfer, the most desirable strategic orientation would be the one coherent with the concept of corporate knowledge network within which knowledge flows are intensive and multidirectional, like the geocentric orientation according to Perlmutter (1969), and the transnational model proposed by Bartlett and Ghoshal (2002). It should be noted however, that within each MNC, even the most integrated, substantial differences between subsidiaries can be observed as far as their strategic roles are concerned, due to their diverse age, specifics of local markets they operate in, and endowment in knowledge resources (embodied in their employees, and embedded in local networks). These differences between subsidiaries are also reflected in their involvement in cross-border transfer (Foss, Torben 2002; Andersson et al. 2002).
} 
- the ability of an assignee to transmit the knowledge, through providing a common code enabling communication (with host unit employees), and facilitating his or her adjustment to work and interactions in an unknown location due to the familiarity of the cultural environment in the workplace (Black et al 1991; Brown 2008; Puck et al. 2003);

- the individual motivation to engage in knowledge transfer (as donor/recipient), and the mutual relationships between transferors (i.e. assignees) and transferees (i.e. host unit employees), as long as it fosters knowledge sharing due to openness and trust (Argyris, Schön 1978; Davenport, Probst 2002; Grudzewski et al. 2008), a sense of safety (Friedman et al. 2003), and concern for positive relationships through integration/socialization mechanisms across borders (Macharzina et al. 2003).

c) Managerial, which encompasses the practices and HRM tools used throughout the whole process of international assignment that enable and facilitate knowledge transfer. As Bonache and Zárraga-Oberty (2008) suggest, the range of supportive solutions within this domain include initiatives:

- addressed to employees who are supposed to transfer knowledge, focused on their abilities and attitudes related with this role (i.e. the extensive selection of candidates including non-technical criteria, monitoring, evaluating, and rewarding knowledge transfer activity);

- addressed to employees who are supposed to absorb or adapt new knowledge, and as a consequence, enhance their own competences (i.e. implementing high work performance systems encouraging the host unit employees to change their behaviour);

- monitoring and facilitating the relationships between transferor and transferee (i.e. extensive socialization, use of intercultural training, coaching, and advising/mediating if conflict occurs).

d) Structural, which includes:

- the occurrence of a common standard of work arrangement in an MNC facilitating the assignees' adjustment ${ }^{7}$;

- the extent to which IA type is compliant with the nature of knowledge to be transferred. For instance, more contextual and less structured

\footnotetext{
${ }^{7}$ In particular, the similarity between sending and recipient units concerning the division of work, job design, job positions, and using common, corporate IT infrastructure increases the perceived familiarity of foreign location, and thus facilitating the adjustment of assignees to work (including teamwork) in a new environment (Black et al 1991; Puck et al. 2003; Hechanova et al. 2003).
} 
knowledge requires probably longer assignments with intensive interactions, while sending a team instead of an individual assignment is a presumably better option for transferring collective tacit know-how (Macharzina et al. 2003; Bonache, Zárraga-Oberty 2008);

- the extent to which the form of co-work with local employees is compliant with the nature of knowledge transfer. For instance, teamwork, group problem solving and lateral relationships, foster knowledge transfer understood as a more symmetric, spontaneous and natural exchange of experience, expertise or ideas; whereas transfer, defined as implementing know-how created by a more advanced unit, can be more effective when the assignee performs the role of a team leader or a trainer responsible for planning, organizing, supporting, and supervising learning activities undertaken by local staff (Macharzina et al. 2003).

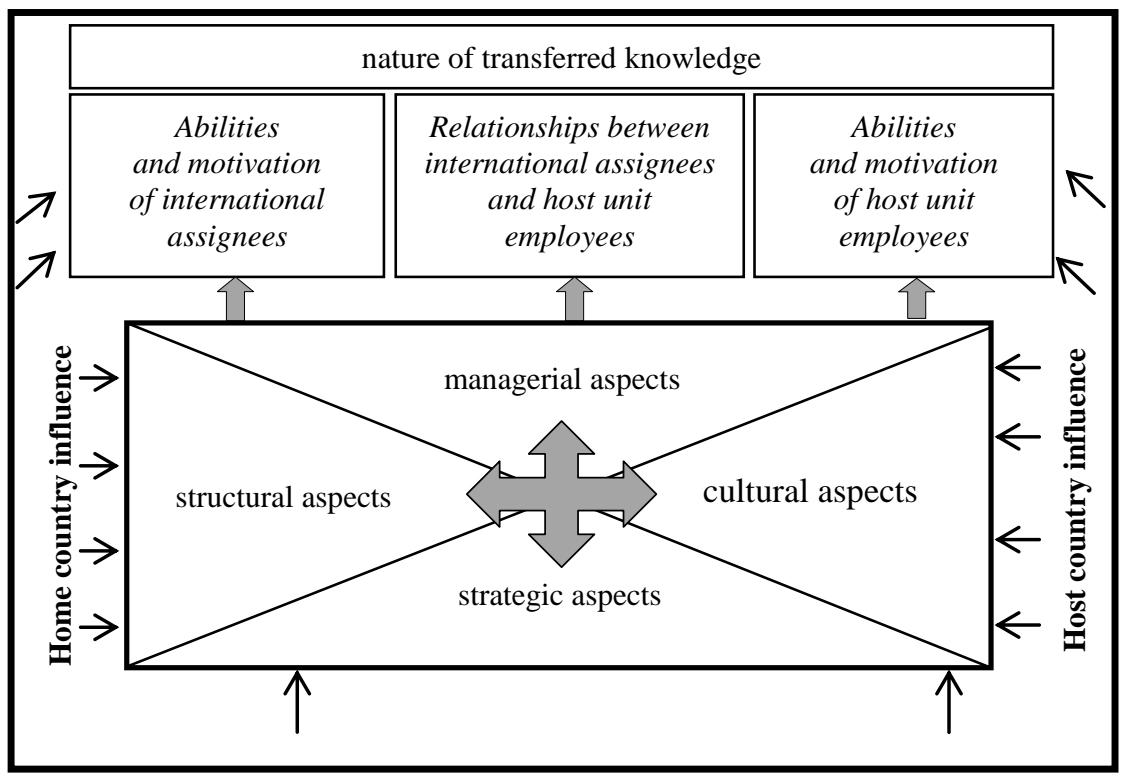

Figure 1. Model of knowledge transfer by means of IAs within the organizational context

Source: own work based on Kostova 1999; Szulanski 2003; Harzing, Noorderhaven 2006; Dickmann, Müller-Carmen 2006; Bonache, Dickmann 2008; Bonache, Zárraga-Oberty 2008

To sum up, when choosing the appropriate type of IA for the purpose of knowledge transfer, it is necessary to take into account a whole configuration of factors, including the nature of knowledge, the 
characteristics of participants and the relationships between them, the occurrence of supportive organizational policies and practices, and other contextual factors as potential sources of disturbances and challenges. Therefore, to illustrate some of the above-mentioned aspects, the Polish experience in cross-border knowledge transfer via IAs is discussed in the following section.

\section{THE POLISH EXPERIENCE IN USING IAS FOR FACILITATING CROSS-BORDER KNOWLEDGE TRANSFER}

The extant literature on expatriation and cross-border transfer relies mostly on empirical evidence from Anglo-Saxon, German and Japanese corporations (Brewster, Scullion 1997), while the occurrence of the above issue in Polish research papers is rather symbolic. Only some of these aspects appear in the context of strategic integrity and trans-corporate communication (Stor 2011), organizational practices and solutions in the scope of human resources management (e.g. Międzynarodowe zarzadzanie... 2002; Zarzadzanie kadra ... 2008; Przytuła 2011, 2014; Zając 2011), and in the studies concerning managing expatriation carried out by A. Pocztowski's team, in which the author participated ${ }^{8}$.

However, almost all the available empirical studies involved respondents who were either expatriates sent to Poland, or managers from foreign subsidiaries located in Poland. A summary of their findings is presented in Table 1.

Most of the above-mentioned empirical studies used managers as a source of information about organizational policies, practices or problems, and more rarely, they focused on the individual experiences of expatriates. They provided results limited to foreign subsidiaries activity (or expatriates in these entities). On one hand, there is no doubt that Polish companies strive to imitate or adjust the solutions and managerial ('best' or at least 'good') practices applied by their foreign peers'. However, on the other hand, comparative studies suggest that the differences between domestic Polish firms and foreign subsidiaries operating in Poland are fairly noticeable (Międzynarodowe zarządzanie ..., 2002: pp. 227 - 229).

\footnotetext{
${ }^{8}$ The results of these studies were discussed, among others in (Purgał-Popiela 2011; PurgałPopiela 2012; Zarzadzanie misjami... 2012).

${ }^{9}$ These processes reflect the influence of foreign direct investments on practices in domestic enterprises in such countries as Poland (see: Pilarska 2007: pp. 101-113).
} 
IAs and cross-border knowledge transfer in Polish literature - a review of related research undertaken between 2003 and 2013

\begin{tabular}{|c|c|c|}
\hline 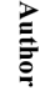 & $\begin{array}{l}\text { Research description: } \\
\text { topic / methodology / sample }\end{array}$ & $\begin{array}{c}\text { Key findings } \\
\text { (concerning cross-border knowledge transfer and/or expatriation) }\end{array}$ \\
\hline 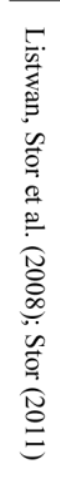 & $\begin{array}{l}\text { Management of managerial staff in } \\
\text { multinational organizations in Poland, HRM } \\
\text { strategies and trans-corporate } \\
\text { communication } \\
\text { (2004-2008) } \\
\text { Methods: structured in-depth interviews and } \\
\text { survey (with the same respondents), content } \\
\text { analysis of organizations' documents, case } \\
\text { analysis } \\
\text { Sample: } 35 \text { subsidiaries operating in Poland, } \\
\text { diversified in term of company size, branch } \\
\text { and country of origin; purposive and snowball } \\
\text { sampling }\end{array}$ & $\begin{array}{l}\text { Strategies of inter-units communication are most often focused on standardization or supporting } \\
\text { transnational solutions, which reflects the importance of using advanced communication technologies. } \\
\text { Institutional objectives seem to be more appreciated than personal communication. } \\
\text { Problems with intercultural communication occur much more often in MNCs with an Asian origin than } \\
\text { in those from North America. The latter more frequently (in comparison to Asian and European) } \\
\text { positively value such characteristics of Polish employees as: general knowledge and skills, encouraging } \\
\text { knowledge sharing, participating in international teamwork, and accepting responsibility. In light of the } \\
\text { respondents opinions, a problematic issue (related with knowledge transfer) is the insufficient use of } \\
\text { solutions developed in Polish subsidiaries by other units of the corporation. } \\
\text { Expatriates are involved in knowledge transfer (to Polish subsidiaries) particularly in early stages of the } \\
\text { subsidiary life cycle, however, the most typical tasks of assignees are: protection of owner's interests, } \\
\text { control of managing process, managing the business and coordination on a strategic level. Those roles of } \\
\text { expatriates suggest that the majority of MNCs operating in Poland tend to continue an ethnocentric } \\
\text { policy even in subsidiaries with a longer 'tenure'. }\end{array}$ \\
\hline 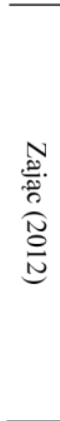 & $\begin{array}{l}\text { Human Resource Management in } \\
\text { International Capital Groups (2002-2004 } \\
\text { and 2005 - 2010) } \\
\text { Methods: case study analysis combined with } \\
\text { using focus group and structured } \\
\text { questionnaire survey } \\
\text { Sample - the same in both stages: nine } \\
\text { subsidiaries of major international corpora- } \\
\text { tions (former Polish companies that were } \\
\text { acquired by foreign investors); purposive } \\
\text { sampling }\end{array}$ & $\begin{array}{l}\text { Problems related with the assimilation of expatriates sent to subsidiaries are very often experienced by } \\
\text { their Polish co-workers, therefore local (Polish) HR managers seek for a variety of supportive measures } \\
\text { (for many reasons including the need for being appreciated, avoiding redundancies and enabling smooth } \\
\text { cooperation between "them" and "us"). Reasons of insufficient assimilation include: poor grasp of } \\
\text { English language by Polish managers, lack of professional training that would prepare expatriates to } \\
\text { work in international corporate structures, the low level of professional competences among Polish } \\
\text { managers and perceiving Polish managers as much less competent by expatriates, HQs do not monitor } \\
\text { properly the expenses linked expatriation which in turn fosters the mismatch between declared principles } \\
\text { and expatriates behaviour, the inadequacy (to Polish reality) of qualifications and the salary expectations } \\
\text { of spouses. There are several important consequences of the problem such as: insufficient } \\
\text { communication between domestic staff and expatriates, division into "us" (better) and "them" (worse), } \\
\text { feelings of being undervalued among Polish managers, an atmosphere of fear and anxiety, frustration } \\
\text { among expatriates. }\end{array}$ \\
\hline
\end{tabular}




\begin{tabular}{|c|c|c|}
\hline & $\begin{array}{l}\text { Cultural barriers in activity of foreign } \\
\text { subsidiaries in Poland }(2009-2010) \\
\text { Methods: semi-structured interviews, analysis } \\
\text { of documents and data from external (public) } \\
\text { sources on MNCs from the sample described } \\
\text { below } \\
\text { Sample: senior and middle-level managers } \\
\text { from } 45 \text { subsidiaries operating in Poland for } \\
\text { at least one year, in which intercultural } \\
\text { interactions take place; purposive and } \\
\text { snowball sampling }\end{array}$ & $\begin{array}{l}\text { The occurrence of institutional and individual ethnocentrism in HQ identified by subsidiary staff of } \\
\text { MNEs was often an important obstacle in subsidiary-HQ relationships. It was manifested in: neglecting } \\
\text { information sent from Polish subsidiaries to HQ, ignoring ideas of a local origin, excessive expatriates' } \\
\text { share in top management and control function, implementing know-how from HQ without sufficient } \\
\text { adjustment to Polish specific (particularly in marketing). In everyday cross-cultural interactions (team } \\
\text { project, meeting etc. in Polish subsidiaries) there were several communication-related problems, such } \\
\text { as: "native speaker syndrome" (emphasizing errors in English made by non-native speakers), the } \\
\text { exclusion of Polish employees from discussion by switching into the expatriates' native language, } \\
\text { unwillingness to use corporate language in mixed teams. }\end{array}$ \\
\hline & $\begin{array}{l}\text { Effectiveness in expatriate management in } \\
\text { Poland (2009-2012) } \\
\text { Methods: survey, content analysis, } \\
\text { participatory observation, direct interviews } \\
\text { Sample: } 76 \text { entities with foreign capital, } \\
\text { which use expatriation in their activities }\end{array}$ & $\begin{array}{l}\text { Polish subsidiaries rarely developed their own expatriation policies, however these policies existed on a } \\
\text { corporate level. Nevertheless, the issue of using assignees' experience and knowledge after their } \\
\text { comeback was neglected, and a minority of HQs monitored the retention or satisfaction of these } \\
\text { employees. The level of accomplishing IAs goals was not measured or monitored in many of the MNEs. } \\
\text { In only } 13 \% \text { of firms IAs were fully successful (= all goals achieved). In a great majority of companies } \\
\text { the real costs of IAs were much higher than the anticipated expenses and there were no clear rules } \\
\text { which linked the remuneration to performance of assignees. Therefore the expatriate management } \\
\text { process cannot be regarded as effective, and subsidiaries do not benefit enough from their HQs' } \\
\text { experience within this realm. }\end{array}$ \\
\hline 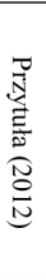 & $\begin{array}{l}\text { Expatriate managerial staff in international } \\
\text { companies in Poland (2011-2012) } \\
\text { Methods: survey and content analysis of } \\
\text { written sources: companies' documentation } \\
\text { and web-based information } \\
\text { Sample: } 111 \text { expatriates working in Polish } \\
\text { branch offices (of foreign MNCs); snowball } \\
\text { sampling }\end{array}$ & $\begin{array}{l}\text { The majority of expatriates sent to Poland were managers from Western Europe. The length of their } \\
\text { assignments very seldom were longer than } 3 \text { years, and more than one third of IAs are short-time } \\
\text { expatriation. The most popular motive of these IAs was know-how transfer (indicated in } 60 \% \text { of all } \\
\text { IAs), one third of assignees also developed local employees and engaged in corporate culture transfer. } \\
\text { Among the major problems affecting their assignments was insufficient knowledge of foreign language } \\
\text { and "Polish bureaucracy" were the most frequently mentioned obstacles. Almost one third of assignees } \\
\text { suffered also from conflicts / difficult relationships with Polish co-workers. }\end{array}$ \\
\hline
\end{tabular}

Source: own study 
Nevertheless, it should be noted that only one of these studies, i.e. the research project undertaken by Pocztowski and colleagues (Zarzadzanie misjami... 2012) included MNEs of Polish origin (see: Table 1). According to this study, in the majority of multinational firms, expatriation was used in order to develop their activities in new markets and to transfer know-how abroad. However, there were substantial differences between Polish companies and the foreign subsidiaries related to the popularity of particular IAs objectives. In particular, assignees acted as know-how transferors in over $80 \%$ of subsidiaries and only in half of Polish companies.

Referring to the concept of the knowledge transfer presented earlier, it should be noted that the above-mentioned survey does not provide any results explaining the nature of this knowledge, neither the information necessary to describe the quality of these relationships nor to characterize the participants of such interactions. Therefore in order to illustrate the key findings and limitations of this paper, the qualitative results are discussed below and summarized in Table 2. As mentioned, such exemplification allows to determine the importance of knowledge transfer in the process of sending employees abroad, to find out organizational solutions supporting/inhibiting knowledge transfers through IAs, and to identify the key challenges accompanying them.

The empirical results are derived from three in-depth semi-structured interviews carried out in 2011 with key informants (managers responsible for expatriation management) representing three multinational companies established in Poland in the 1990s (see: Table 2), and available documents and web-based resources as supplementary sources of data. These interviews were primarily aimed to draw a complete picture of the managing of international assignments, thus knowledge transfer was not the key issue ${ }^{10}$. Nevertheless, such an approach provides an opportunity to grasp knowledge transfer-related tasks and challenges in a wider and natural context, as in practice it is difficult to separate this issue from the other roles of assignees.

The analysed companies were large employers representing diverse industries. They all began their international expansion as exporters, and currently operate only in Europe, including the Eastern part (Russia and/or

\footnotetext{
${ }^{10}$ Each interview was carried out in accordance with the same scenario consisting of open questions concerning the following issues: strategic importance of IAs (occurrence of coherent, formal strategy/ policies), organizational and individual goals and roles fulfilled by assignees, supporting assignees in preparing for the assignment and performing assigned tasks during their stay abroad, consequences of IAs for individuals, problems experiences by assignees, including performing their roles and interacting with local staff, the key success factors affecting IAs.
} 
Ukraine), which are typical locations of foreign direct investments made by Polish entrepreneurs (Karaszewski et al. 2009). The number of international assignees varied per year from 10 to 40 . Common characteristics of all firms were the dominance of the headquarters in managing expatriation, and corresponding with this position the traditional direction of cross-border employee flow, i.e. from HQ to subsidiaries.

The assignees fulfilled several roles, including knowledge transfer. Nevertheless, the latter rarely was the priority of their activity, except for short-term IAs in the second MNE. All companies used non-standard IAs ${ }^{11}$, which is not a surprise if compared with the results obtained by Pocztowski's team (Zarzadzanie misjami... 2012) from the surveyed Polish companies operating abroad. Yet in the first company, international business travels (IBTs) were the only solution, whereas in the second and the third firm, a variety of IAs were used.

All these firms clearly preferred internal candidates for expatriation, however it was not always possible to find them (see: the third example in Table 2). The recruitment and selection of candidates for non-standard assignments can be characterized as a less formalized process based on screening documents and interviews or talks with applicants who were expected to demonstrate their professional/technical competences and grasp of local language (stressed by interviewees as an important feature of work in Eastern Europe). Long-term expatriation involved more sophisticated methods aimed to assess congruence (of candidate competences) with the competence profile (in the second and the third examples). Practices concerning the preparation of candidates differed substantially, which reflected diverse assumptions about the assignees. For instance, in the second company the candidate was expected to take the initiative and define his or her needs, while in the third, participation in formalized programs (about particular localizations) was obligatory for assignees. According to the interviewees, company assistance depended on the type of IAs. In particular, the main facets considered when determining the scope of such support were the length of sojourn and the presence of family members. The type of task/assignee's role did not matter. Nevertheless, ensuring accommodation and car/transport to the workplace was a standard solution.

In each company the issue of performance management was treated in a flexible, less formalized manner, and focused on the assignees'

\footnotetext{
11 These non-standard IAs encompassed: short term - lasting up to 3 months, extended assignments - up to one year, international business travels used by flexpatriates, who frequently leave their home unit and are sent abroad for no longer than a few weeks (Mayerhofer et al. 2004; Dowling et al. 2008).
} 
Table 2

Summary of analysis: IAs in Polish MNEs

\begin{tabular}{|c|c|c|c|}
\hline $\begin{array}{c}\text { Source of } \\
\text { information }\end{array}$ & Key characteristics of IAs & Organizational activities accompanying IAs & $\begin{array}{l}\text { Interaction-related challenges } \\
\text { occurring during assignments }\end{array}$ \\
\hline 1 & 2 & 3 & 4 \\
\hline $\begin{array}{l}\text { HR Manager } \\
\text { engaged in IAs } \\
\text { matters } \\
\text { Large Polish } \\
\text { MNE } \\
(25,000 \\
\text { employees) } \\
\text { established in } \\
1992, \\
\text { specialized in } \\
\text { furniture } \\
\text { industry }\end{array}$ & $\begin{array}{l}23 \text { international business } \\
\text { travellers (from internal labour } \\
\text { market) } \\
\text { Length of assignments: } 2-3 \\
\text { weeks } \\
\text { Most important localizations: } \\
\text { Slovakia, Hungary, Ukraine, the } \\
\text { UK, Germany, France } \\
\text { Main tasks of assignees: } \\
\text { - Integration of processes in } \\
\text { newly acquired entities } \\
\text { - (currently most important) } \\
\text { - Managing / participating in } \\
\text { project (within IT, finance, } \\
\text { logistic, distribution, } \\
\text { purchasing) } \\
\text { Typical roles of assignees: } \\
- \text { Developing activity on new } \\
\text { markets } \\
\text { - Teaching employees } \\
\text { - Knowledge transfer } \\
\text { - Improving communication } \\
\text { between HQ and subsidiary } \\
\text { - Building corporate culture } \\
\text { - Consulting and problem- } \\
\text { solving } \\
- \text { Control/ integration of } \\
\text { business processes }\end{array}$ & $\begin{array}{l}\text { There is no formal procedure related to expatriation, however, there are well- } \\
\text { known organizational practices. } \\
\text { Managing expatriation is a domain of the headquarters, the role of host } \\
\text { subsidiary is to support organization of accommodation and dealing with } \\
\text { administrative issues. } \\
\text { Recruitment and selection of candidates consists of informing directly } \\
\text { potential assignees, screening of documents and interview with them. } \\
\text { Criteria of selection include: grasp of local language, professional } \\
\text { competences/ expertise, interpersonal competences, personal situation (to a } \\
\text { small extent). } \\
\text { Preparation to expatriation is based on communication with the supervisor } \\
\text { (responsible for the process) and co-worker from the host unit. Assistance } \\
\text { from the company is limited to ensuring accommodation and company car. } \\
\text { There is neither a formal appraisal nor performance management system. } \\
\text { The supervisor in HQ defines the goals and tasks, and after completing IA } \\
\text { evaluate performance against his/her expectations. } \\
\text { Remunerating policy is discretional, bonuses are paid if performance is } \\
\text { satisfactory (according to supervisor) }\end{array}$ & $\begin{array}{l}\text { "Sometimes relationships [between Polish } \\
\text { assignees and host unit employees] are } \\
\text { difficult due to the fact that in Germany or UK, } \\
\text { employees do not put trust in competences of } \\
\text { Polish specialists. [Therefore] the company is } \\
\text { trying to hire local managers with Polish roots } \\
\text { as members of the board". } \\
\text { According to the source, IAs are successful } \\
\text { since many problems are solved via virtual } \\
\text { communication/ virtual project teams and } \\
\text { "expatriation is limited to absolutely } \\
\text { necessary [situations]". As key factor he } \\
\text { defined was "the way of performing tasks } \\
\text { abroad without the necessity to stay there for a } \\
\text { long period of time" }\end{array}$ \\
\hline $\begin{array}{l}\text { Managing } \\
\text { Director of BU } \\
\text { (responsible } \\
\text { for managing }\end{array}$ & $\begin{array}{l}\text { Ten expatriates (managers from } \\
\text { internal labour market) } \\
\text { Length of assignments: mostly } 2 \\
-3 \text { years, short - time }\end{array}$ & $\begin{array}{l}\text { Process of managing expatriates is formalized, documents describe the } \\
\text { content of the job, recruitment and selection, remuneration policy etc. } \\
\text { Managing expatriation is a domain of headoffice (Managing Director (MD) } \\
\text { is the decision-maker, HR department provide necessary services), the role }\end{array}$ & $\begin{array}{l}\text { "An expatriate is solely responsible for } \\
\text { adaptation [in host country], HR department } \\
\text { does not interfere ... only observes how he/she } \\
\text { copes with it... in the case of families it }\end{array}$ \\
\hline
\end{tabular}


IAs)

Large Polish MNE (4900 employees) established in 1990 , operating in food industry assignments for purposes of know-how/ technology transfe Most important localization:

Czech Republic, Slovakia,

Hungary, Russia, Bulgaria,

Romania, Ukraine

Typical roles of assignees:

- Control of subsidiary activity (most important)

- Managing subsidiary

- Developing activity on new markets

- Training employees

- Knowledge transfer

- Improving communication between HQ and subsidiary

- Building corporate culture

- Consulting and problemsolving of host subsidiary includes: dealing with administrative issues, assisting in relocation and accommodation, evaluating behaviour and attitudes during assignment, ensuring training on work specifics/ requirements in host country. Candidates for short-time assignments aimed to transfer of knowledge are recruited in an informal way on the basis of their professional

competences/experience and grasp of host language (key criterion).

Recruitment for long-time IAs involves informing employees about the offered documents, and carrying out assessment centre and/or skills tests and psychological tests by corporate HR department (in order to diagnose motivation and check congruence of possessed and required competences). Final stage is interviewing candidates by $\mathrm{MD}$ (including negotiating the remuneration package). Common criteria of selection include: adequate competences, grasp of host language, preferable - previous international experience, family situation has no influence on accepting the candidate. Preparation to expatriation is designed individually in form of internal training and language course (external). The length of it depends on individual needs, on average it takes about $1-2$ months. Typically the program contains at least one pre-departure trip to the host country (offered also to accompanying family members). As assignees derive from among managers, they are expected to take the initiative and independently determine what solutions are needed to prepare. Then, the company may offer them financial support.

Assistance from the company depends on the type of assignment. Long-term expatriates benefit from accommodation, company car, organizational and financial help in children's education matters, help in career matters in the case of spouse, while short-time assignees have to leave their families and can frequently travel to Poland (on company account)

There is neither formal appraisal nor performance management system in host units, but they evaluate qualitative criteria in an informal way. The supervisor in HQ defines the goals and tasks, which are monitored and evaluated every six months. Additionally, the MD compares costs and effect of selected sub-processes of expatriation

Remunerating policy is a company secret.

The MD is responsible for repatriation and career planning, however the corporate HR department is supposed to ensure appropriate (updating) training. From 6 to 3 months before the date of return (which is always known to the assignee) the MD contacts the employee in order to arrange further career development (usually: further career development (usually: promotion or another expatriation).
Each assignee (before departure) is offered a guarantee to obtain at least Each assignee (before departure) is offered a guara
comparable job/ employment condition after return happened that some wives couldn't adjust to the new reality at all."

About working in Russia, Romania, Ukraine "different approach to doing business",

"problems with communication [with host employees], "they are not prepared to our

standards, of work, which leads to frustration" In general:

"There are no problems with remuneration and benefits. Mainly [there are] caused by different mentalities, leadership styles, cultural context"

"The main problem is coming back [of an assignee] and finding the right job for the returning expatriate ... sometimes [it is] the approach of expatriate ... from the very beginning [of assignment] the remuneration package is formalized, but it happens that the expatriate expects more, for example ... the winter in the host country begins too soon, at the beginning there is a hurray-optimism, and later, the cultural shock"

"The biggest problem for the company is when the expatriate 'goes off' for example ... in the middle of a foreign assignment. The question is whether to wait or look for a substitute ... is therefore important for the company to recruit employees and prepare them to go abroad"

About the transfer of knowledge from the host unit to HQ through employees flows: "Rarely there is such a transfer ... affiliates have usually a much lower level of experience" 
Table 1, cont.

\begin{tabular}{|c|c|c|c|}
\hline 1 & 2 & 3 & 4 \\
\hline $\begin{array}{l}\text { HR Manager } \\
\text { engaged (in } \\
\text { IAs matters) } \\
\text { large Polish } \\
\text { MNE (2000 } \\
\text { employees) } \\
\text { established in } \\
\text { 1996, operating } \\
\text { in construction } \\
\text { industry }\end{array}$ & $\begin{array}{l}40 \text { expatriates, including senior } \\
\text { managers (15) and middle-level } \\
\text { (25) from both internal and } \\
\text { external labour markets } \\
\text { Length of assignments: from } \\
\text { several months to } 3 \text { years } \\
\text { Most important localizations: } \\
\text { Finland, Netherlands, Russia, } \\
\text { Sweden, Estonia } \\
\text { Typical roles of assignees: } \\
\text { - Managing the project } \\
\quad \text { (contract with foreign client, } \\
\text { performed with local } \\
\text { subcontractors) } \\
\text { - Developing activity on new } \\
\text { markets } \\
\text { - Teaching and training } \\
\text { employees } \\
\text { Specific role of IAs - in Russia } \\
\text { - Using expatriation and } \\
\text { inpatriation } \\
\text { - Know-how transfer } \\
\text { - Implementation of corporate } \\
\text { values } \\
\text { - Training local employees } \\
\text { (particularly managers) }\end{array}$ & 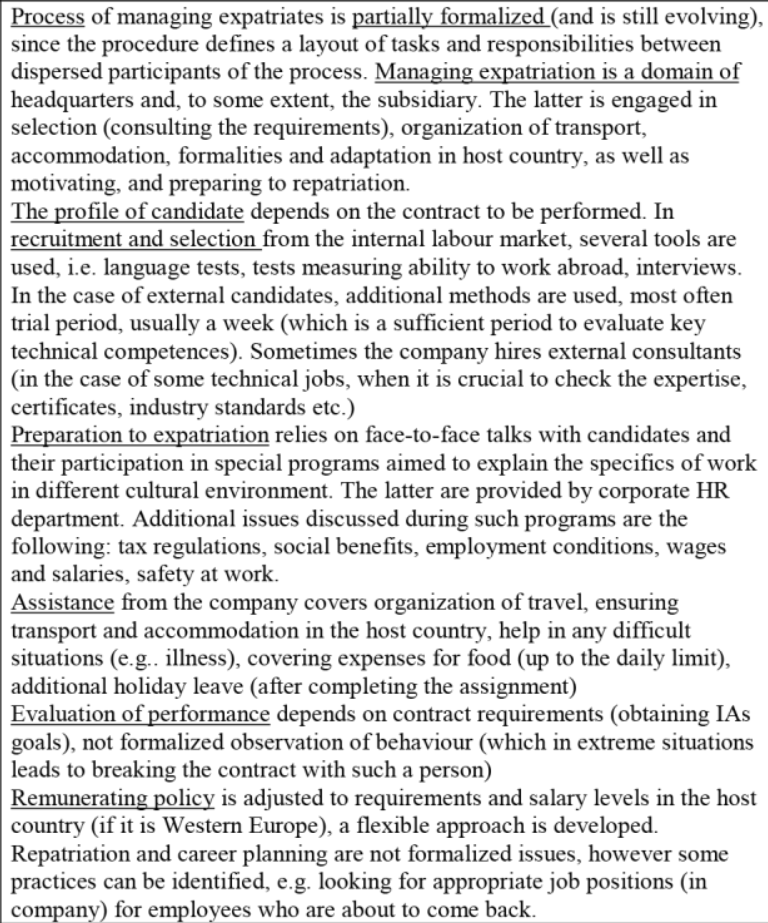 & $\begin{array}{l}\text { "Unfortunately, limited human resources } \\
\text { [available for IAs] made the company use } \\
\text { external labour market [which resulted in] } \\
\text {..tensions and conflicts between own } \\
\text { employees [with long tenure in the company] } \\
\text { and those recruited from the external labour } \\
\text { market" } \\
\text { "When it comes to relationships with } \\
\text { employees of other nationalities (...) Polish } \\
\text { managers lack confidence in dealing with } \\
\text { them. The reasons for this can be seen in the } \\
\text { low linguistic competence of Polish workers } \\
\text { and the characteristics of the organizational } \\
\text { culture as an engineering organization, } \\
\text { striving for perfection in performing contracts } \\
\text { and clearly defined tasks but having trouble } \\
\text { with coming up with new things." } \\
\text { "Despite the high activity of the training } \\
\text { company (nowlinguisticallytrained120persons), } \\
\text { we are affected by lack of language skills" } \\
\text { Premature returns happen because of "burnout } \\
\text {.. people sometimes do not stand up mentally } \\
\text { working abroad", "some employees leave } \\
\text { during the assignment (...) they find better } \\
\text { remuneration condition" and "motivation is of } \\
\text { a highly financial nature" } \\
\text { "How to keep them [i.e. assignees] in the } \\
\text { company using their experience gained abroad } \\
\text { is a big challenge, with which at the moment } \\
\text { the company cannot cope" }\end{array}$ \\
\hline
\end{tabular}

Source: own study based on empirical evidence (transcribed interviews carried out by Pocztowski's team in 2011) 
success/failure in achieving goals or completing the tasks. As a consequence, the remuneration policies tended to be discretional and context-dependant. It comes as a surprise that only one firm had a clear policy concerning repatriation and career development. Apparently such a practice could have contributed to the higher organizational commitment of the assignees, since the turnover in this category of employees was hardly noticeable.

Apart from organizational practices affecting relationships with locals, performing tasks and adjustment to a novel location, the study highlighted several challenges related to IAs and the problems of knowledge transfer.

Firstly, there were difficulties in developing good relationships and ensuring smooth cooperation between delegated Polish managers and their local peers and/or subordinates. What is more, the reasons differed according to localization or nationality, e.g. lack of trust in the competences of Polish managers in Western units, different approaches to work, conducting business, and discipline in Eastern units. On one side, some Polish managers demonstrated an ethnocentric attitude (towards employees from Eastern Europe), on the other, they were blamed for insufficient language skills and lack of confidence. In effect, the success of knowledge transfer might be doubtful, since the transferor is not perceived as a trustworthy expert and/or source of valuable information/skills.

Secondly, there were some symptoms of maladjustments (concerning expatriates without previous international experience and merely accompanying spouses), premature returns (due to emotional problems), unrealistic expectations which involved cultural shock as the result of a clash with reality, and psychological withdrawal (when an expatriate 'goes off' in the second company). Consequently, the opportunity to benefit from fruitful intercultural interaction could have been lost or remained unnoticed.

Thirdly, establishing long-term psychological contract and ensuring the loyalty of expatriates were highly problematic. This situation was the joint effect of external influences (shortage of candidates with experience in international management, changing career patterns, and increasing competition between employers), and organizational incapability (lack of clear repatriation/career policy and attractive opportunities). In such conditions of insufficient satisfaction, and anxiety about the future, the individuals would not be willing to share their knowledge or fully engage in teaching others. 


\section{CONCLUSIONS AND IMPLICATIONS FOR FURTHER RESEARCH}

The results discussed in the previous section suggest that knowledge transfer in Polish MNEs was an additional task of the assignees which focused on such company priorities as developing activity in new markets, or managing/controlling overseas subsidiaries or business processes/ operations performed abroad. Similarly to Western corporations, these MNEs used a range of IAs, including non-traditional solutions, although the latter were preferred (by one of them) as a mode of knowledge transfer. However, the prevailing direction of cross-border knowledge flows by means of IAs remained traditional, i.e. from headquarters to a subsidiary, which means that they rarely can benefit from local expertise or ideas. The Polish headquarters were a strongly dominant party, or even the only actor in the process of managing IAs, whereas host subsidiary participation was rather symbolic. Regarding the recruitment of candidates for IAs, organizational practices varied, and the type of assignment played a major role here (in particular, it affected the criteria and methods of selection). Preparation for expatriation reflected the companies' assumptions about the roles and needs of assignees. In cases of longer assignments, it usually included the development of the assignees abilities necessary for transferring knowledge or components that enhance the opportunity to establish positive relationships with the host unit's employees. Performance management was limited to rather informal assessing, whether or not an assignee met the expectations regarding goals/tasks. Nevertheless the interviews did not provide information about the presence of any criteria related to knowledge transfer roles.

A list of the challenges identified in the mentioned companies contained the following issues: (1) establishing relationships between assignees and host co-workers based on mutual trust and belief that both parties have valuable experience/expertise, and thus both parties will benefit from knowledge sharing, (2) supporting assignees and monitoring their adjustment processes before and during the assignments (because pre-departure training is not sufficient support, and because maladjustment results in poor performance), (3) developing career and repatriation policies addressed to assignees, which are based on in-depth analyses of individual expectations and competencies, appreciate their international experience, and make use of it after completing the assignment. It is worth mentioning that some of these were also noticed by other researchers in foreign subsidiaries, e.g. ethnocentric attitudes demonstrated in relationships with local staff, and insufficient assimilation of expatriates (see: Table 1). 
Among the multiple limitations of the above analysis, the following constraints could be identified: a small sample containing companies of similar size and history, the incompleteness of information concerning organizational context (i.e. corporate strategy and culture, work arrangements in host units) and the specifics of host units (i.e. their roles and status within the corporation, experience and competences of staff), including only one point of view (managers responsible for managing IAs), and the lack of insight in the nature of the transferred knowledge.

Since this was an initial exploration, it evokes many doubts and questions like:

(1) What characteristics of organizational policies and practices are perceived as crucial facilitators in cross-border knowledge transfer from the perspective of its direct participants (i.e. assignees and host unit employees)?

(2) To what extent the identified policies and practices of managing IAs reflect the influence of cultural factors (e.g. the role of uncertainty avoidance and power distance as the parameters that might affect assignees' roles and the occurrence of obstacles referring to knowledge sharing or teaching others)?

(3) Whether and to what extent the specifics of recipient unit location affects the priorities and directions of expatriation aimed at knowledge transfer?

Finally, it should be noted that the complete application of the proposed conceptual framework in analysing the issue of knowledge transfer by means of IAs, requires a balanced use of different sources of information located both within and outside the company. The suggested scope of such research encompasses both aspects of the relationship established for knowledge transfer, i.e. interpersonal (i.e. transferor - transferees) and inter-unit (home - host). Additionally, longitudinal studies based on the proposed framework would help clarify the nature of the linkage between performing the roles of knowledge transferor and transferees, and the organizational support within particular phases of the assignment (i.e. preparation, beginning, middle and final stage of sojourn, and post-assignment - when its consequences can be identified and evaluated). 


\section{REFERENCES}

Andersson, U., Björkman, I., Furu, P., Subsidiary Absorptive Capacity, MNC Headquarters' Control Strategies and Transfer of Subsidiary Competencies, [in:] Lundan, M. S., (ed.) Network Knowledge in International Business, pp. 115-136. Edward Elgar, Cheltenham (UK)/Northampton (USA), 2002.

Argyris, C., Schön, D. A., Organizational Learning: A Theory of Action Perspective. Addison-Wesley, Reading, Massachusetts, 1978.

Bartlett, C. A., Ghoshal, S., Managing Across Borders: The Transnational Solution. Harvard Business School Press, Boston, Massachusetts, 2002.

Black, J. S., Mendenhall, M., Oddou, G., Towards a Comprehensive Model of International Adjustment: An Integration of Multiple Theoretical Perspectives, "Academy of Management Review", 16 (2), pp. 291-317, 1991.

Bonache, J., Brewster, C., Knowledge Transfer and the Management of Expatriation, "Thunderbird International Business Review", 43(1), pp. 145-168, 2001.

Bonache, J., Dickmann, M., Transfer of Strategic Know-how in MNCs: Mechanisms, Barriers and Initiatives [in:] Dickmann, M., Brewster, Ch., Sparrow, P. (eds.), International Human Resource Management. A European Perspective, pp. 67-84. Routledge, London/New York, 2008.

Bonache, J., Zárraga-Oberty, C., Determinants of the Success of International Assignees as Knowledge Transferors: A Theoretical Framework, "International Journal of Human Resource Management", 19 (1), pp. 1-18, 2008.

Brewster, C., Scullion, H., A Review and Agenda for Expatriate HRM, "Human Resource Management Journal", 7(3), pp. 32-41, 1997.

Brown, R. J., Dominant Stressors on Expatriate Couples During International Assignments, "International Journal of Human Resource Management", 19(6), pp. 1018-1034, 2008.

Davenport, T. H., Probst, G. J. B., Knowledge Management Case Book. Best Practices. Publicis Corporate Publishing John Wiley \& Sons. Berlin/Minch., 2002.

Dickmann, M., Doherty, N., Mills, T., Brewster, Ch., Why Do They Go? Individual and Corporate Perspectives on the Factors Influencing the Decision to Accept an International Assignment, "International Journal of Human Resource Management", 19(4), pp. 731-751, 2008.

Dickmann, M., Müller-Carmen, M., Configuring for IHRM Innovation: A Typology and Empirical Assessment of Strategies, Structures and Processes of International HRM, "International Journal of Human Resource Management", 17(4), pp. 580-601, 2006.

Doherty, N., Brewster, C., Suutari, V., Dickmann, M., Repatration. The End or the Middle? [in:] Dickmann, M., Brewster, Ch., Sparrow, P., (eds.), International Human Resource Management. A European Perspective, pp. 174-191. Routledge, London/New York, 2008.

Dowling, P. J., Festing, M., Engle, A., International Human Resource Management, Fifth Edition. Thomson Learning, London, 2008.

Edstörm, A., Galbraith, J. R., Transfer of Managers as a Coordination and Control Strategy in Multinational Organizations, “Administrative Science Quarterly”, 22(2), pp. 248-263, 1977.

Evans, P., Pucik, V., Björkman, I., The Global Challenge, International Human Resource Management, 2nd ed., McGraw-Hill Irwin, New York, 2011. 
Executive Report, CreME, Cranfield School of Management, Cranfield, www.wfpma.com/publications/PDFs/wlv10n4.pdf, 2000.

Foss, N. J, Pedersen, T., Sources of Subsidiary Knowledge and Knowledge Transfer in MNCs, [in:] Lundan, M. S. (ed.), Network Knowledge in International Business, pp. 91-115. Edward Elgar, Cheltenham (UK)/Northampton (USA), 2002.

Friedman, V. J., Lipshitz, R., Overmeer, W., Creating Conditions for Organizational Learning, [in:] Dierkes, M., Antal, B.A., Child, J., Nonaka, I. (eds.), Handbook of Organizational Learning and Knowledge, pp. 757-774. Oxford University Press, New York, 2003.

Grudzewski, W. M., Hejduk, I. K., Sankowska, A., Trust Management - The New Way in the Information Society, "Journal of Economics and Organization of Future Enterprise", 2(2), pp. 2-8, 2008.

Gupta, A. K., Govindarajan, V., Knowledge Flows within Multinational Corporations, "Strategic Management Journal", 21 (4), pp. 473-496, 2000.

Hansen, M. T., Nohria, N., Tierney, T., What's Your Strategy for Managing Knowledge?, "Harvard Business Review", March - April, pp. 106-116, 1999.

Harzing, A. W., Noorderhaven, N., Knowledge Flows in MNCs: An Empirical Test and Extension of Gupta \& Govindarajan's Typology of Subsidiary Roles, "International Business Review" 15 (3), pp. 195-214, 2006.

Harzing, A. W., Sorge, A. M., The Relative Impact of Country-of-origin and Universal Contingencies on Internationalization Strategies and Corporate Control in Multinational Enterprises: Worldwide and European Perspectives, "Organization Studies", 24(2), pp. 187-214, 2003.

Hechanova, R., Beehr, T. A., Christiansen, N. D., Antecedents and Consequences of Employees' Adjustment to Overseas Assignment: A Meta-analytic Review, “Applied Psychology: An International Review”, 52 (2), pp. 213-236, 2003.

Hofstede, G., Hofstede, J. G., Kultury i organizacje: zaprogramowanie umystu [Cultures and Organizations. Mind Programming]. PWE, Warszawa, 2007.

Karaszewski, W., Jaworek, M., Kuzel, M., Szałucka, M., Szóstek, A., Długołęcka, K., Foreign Direct Investment of Polish Companies: Its Scale, Structure, Determinants, Influence on the Competitiveness. Wydawnictwo Naukowe Uniwersytetu Mikołaja Kopernika, Torun, 2009.

Kogut, B., Zander, U., Knowledge of the Firm and the Evolutionary Theory of the Multinational Corporation, "Journal of International Business Studies", 24(4), pp. 625645, 1993.

Kostova, T., Transnational Transfer of Strategic Organizational Practices: A Contextual Perspective, “Academy of Management Review”, 24(2), pp. 308-324, 1999.

Marcharzina, K., Oesterle, M.-J., Brodel, D., Learning in Multinationals [in:] Dierkes, M., Antal, B. A., Child, J., Nonaka, I., (eds.) Handbook of Organizational Learning and Knowledge, pp. 631-656. Oxford University Press, New York, 2003.

Mayerhofer, H., Hartmann, L. C., Michelitsch-Riedl, G., Kollinger, I., Flexpatriate Assignments: A Neglected Issue in Global Staffing, "International Journal. of Human Resource Management”, 15(8), pp. 1371-1389, 2004.

Międzynarodowe zarzadzanie zasobami ludzkimi [International Human Resources Management] [in:] Pocztowski, A. (ed.), Oficyna Ekonomiczna, Kraków, 2002. 
Nahapiet, P., Goshal, S., Social Capital, Intellectual Capital and the Organizational Advantage, "Academy of Management Review", 23 (2), pp. 242-266, 1998.

Perlmutter, H. V., The Tortuous Evolution of the Multinational Corporation, "Columbia Journal of World Business", 4, pp. 9-18, 1969.

Pilarska, Cz., Efekty oddziaływania bezpośrednich inwestycji zagranicznych na rynek pracy w Polsce [Effects of the Influence of Foreign Direct Investments in the Labour Market in Poland] [in:] Kopycińska, D. (ed.), Wykorzystanie zasobów pracy we wspótczesnej gospodarce [Using the Work Resources in Contemporary Economy], pp. 101-113. Wyd. Uniwersytetu Szczecińskiego, Szczecin, 2007.

Polanyi, M., Personal Knowledge: Towards a Post-Critical Philosophy. University of Chicago Press, Chicago, 1962.

Przytuła, S., Expatriates in Poland: Preliminary Empirical Research Results, "Human Resource Management", 6 (89), pp. 89-103, 2012.

Przytuła, S., Zarządzanie kadrą ekspatriantów $w$ filiach przedsiębiorstw międzynarodowych $w$ Polsce [Managing Expatriates in Subsidiaries of Multinational Enterprises in Poland], Wyd. CeDeWu, Warszawa, 2014.

Puck, J. F., Holtbrügge, D., Dölling, S. A., Determinants and Consequences of Expatriate Adjustment: A Review of Existing Studies, Working Paper, No. 3. Friedrich Alexander Universität Erlangen-Nürnberg, Betriebswirtschaftliches Institut, 2003.

Purgał-Popiela, J., Sukces misji zagranicznej i jego uwarunkowania-spojrzenie z perspektywy organizacji i ekspatrianta [Success of International Assignment and Its Determinants Perspectives of Organization and Expatriate], „Problemy Zarządzania”, Vol. 9, No. 4(34), pp.75-97, 2011.

Purgat-Popiela J., Modern Forms of Expatriation in Developing Companies on International Markets, "Human Resource Management", 6 (89), pp. 37-52, 2012.

Rażniewski, K., Study into Efficiency in the Process of Expatriate Management in Poland: Research Communiqué, "Human Resource Management", 6(89), pp. 104-114, 2012.

Reiche, B. S., The Inpatriate Experience in Multinational Corporations: An Exploratory Case Study in Germany, "International Journal of Human Resource Management", 19(9), pp.1579-1591, 2006.

Rozkwitalska, M., Bariery w zarządzaniu międzykulturowym. Perspektywa filii zagranicznych korporacji transnarodowych [Barriers in Cross-Cultural Management. Perspective of Foreign Subsidiaries of Transnational Corporations], Oficyna a Wolters Kluwer business, Warszawa, 2011.

Starr, T. L., Repatriation and Short-term Assignments: An Exploration into Expectations, Change and Dilemmas, "International Journal of Human Resource Management", 20(2), pp.286-300, 2009.

Starr, T. L., Currie, G., 'Out of Sight but Still in the Picture': Short-term International Assignments and the Influential Role of Family, "International Journal of Human Resource Management”, 20 (6), pp. 1421-1438, 2009.

Stor, M., Strategiczne międzynarodowe zarządzanie zasobami ludzkimi [Strategic International Human Resource Management], seria: „Monografie i Opracowania” nr 198. Wyd. Uniwersytetu Ekonomicznego we Wrocławiu, Wrocław, 2011.

Szulanski, G., Sticky Knowledge. Barriers to Knowing in the Firm. Sage Publications, London, 2003. 
Teece, D., Pisano, G., Shuen, A., Dynamic Capabilities and Strategic Management, "Strategic Management Journal", 18(7), pp. 509-533, 1997.

Zając, C., Cultural and Personnel Problems in the Management of Human Resources in International Capital Groups in Light of Empirical Research, "Human Resource Management", 6(89), pp. 72-88, 2012.

Zarzadzanie kadra menedżerska $w$ organizacjach międzynarodowych $w$ Polsce [Managing Executives in International Organizations in Poland], Listwan, T., Stor, M. (eds.), Wyd. Uniwersytetu Ekonomicznego we Wrocławiu, Wrocław, 2008.

Zarzadzanie misjami zagranicznymi. Organizacyjne $i$ indywidualne aspekty pracy ekspatriantów [Managing International Assignments. Organizational and Individual Facets of Expatriates' Work], Pocztowski, A. (ed.), Oficyna a Wolters Kluwer business, Warszawa, 2012.

Zhu, Z., Knowledge Management: Towards a Universal or Cross-Cultural Context?, "Knowledge Management Research \& Practice" 2, pp. 67-79, 2002.

Received: September 2013, revised: March 2015

Acknowledgment: This paper came into being within the research project financed by the National Science Centre, based on decision No. DEC-2012/07/D/HS4/00741 